See discussions, stats, and author profiles for this publication at: https://www.researchgate.net/publication/327402674

Parliamentary involvement, party ideology and majority-opposition bargaining: Belgian participation in multinational military operations

Article in Contemporary Security Policy · July 2018

DOI: 10.1080/13523260.2018.1500819

\section{CITATIONS}

4

3 authors:

D. Daan Fonck

1. KU Leuven

12 PUBLICATIONS 32 CITATIONS

SEE PROFILE

3. Yf Reykers

Maastricht University

32 PUBLICATIONS 55 CITATIONS

SEE PROFILE

Some of the authors of this publication are also working on these related projects:

Project The Politics of Multinational Military Operations View project

Project Parliamentary control over military interventions View project
READS

47

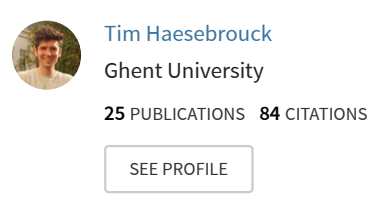




\title{
Parliamentary involvement, party ideology and majority-opposition bargaining: Belgian participation in multinational military operations
}

\author{
Daan Fonck $^{\mathrm{a}}$, Tim Haesebrouck ${ }^{\mathrm{b}}$ and Yf Reykers ${ }^{\mathrm{a}}$ \\ ${ }^{\text {a }}$ Leuven International and European Studies, KU Leuven, Leuven, Belgium; ${ }^{\mathrm{b}}$ Ghent Institute for \\ International Studies, Ghent University, Ghent, Belgium
}

\begin{abstract}
This article examines the impact of parliamentary involvement in troop deployment decisions on restrictions on military mandates by examining the Belgian contribution to the 2011 Libya intervention and the coalition against the self-proclaimed Islamic State. More specifically, we analyse (1) the effect of party ideology on mandate preferences, and (2) the impact of bargaining between majority and opposition parties on the outcome of mandate negotiations. On the former, our case study demonstrates that left-wing parties showed a strong inclination towards imposing restrictions on the use of military force beyond humanitarian goals, while right-wing preferences tend to depend on the national interests at stake in the operation. With regard to majority-opposition bargaining; our study shows that the impact of opposition parties is dependent on the degree of contention between government and opposition parties, as well as on the extent to which the executive needs to seek support across its own majority.
\end{abstract}

Keywords: Caveats; coalition warfare; political parties; legislative-executive relations

Whether having a democratic political system constitutes a liability or an advantage when fighting wars has a been a contentious issue ever since the authoritarian Sparta defeated the democratic Athens in the Peloponnesian War (Desch, 2002, pp. 5-6). Realists like Hans Morgenthau and E.H. Carr suggest that significant mass influence has a detrimental impact on the effectiveness of the foreign policy of democratic regimes. In contrast, so-called democratic triumphalists point out that democracies have been at the winning side of most wars since 1815 (Desch, 2002). More recently, scholars started examining whether or not democracies are more or less reliable allies in multinational coalitions, with authors like Patrick Mello (2018) and Atsushi Tago (2009) pointing out that the reliability of democratic allies primarily depends on domestic political conditions.

Research on national caveats, or national restrictions on what coalition militaries are 
allowed to do, has arrived at a similar conclusions. In their groundbreaking work on the North Atlantic Treaty Organization's (NATO) International Security Assistance Force (ISAF) operation in Afghanistan, Stephen Saideman and David Auerswald (2012, 2014) demonstrate that these restrictions are largely driven by domestic political institutions. Likewise, the comparative case study of Per Marius Frost-Nielsen (2017) of Denmark's, the Netherlands', and Norway's contributions to the NATO-led intervention of 2011 in Libya shows that whether or not states impose restrictions on their forces can best be explained by domestic factors. Strikingly, however, the impact of one domestic institution on national restrictions remains underexplored in the literature on caveats: parliamentary involvement in decisions on the use of force. While prior research provides evidence that participation in (coalition) warfare is less likely if the legislative branch is involved in military deployment decisions (cf. inter alia Mello, 2014; Dieterich, Hummel \& Marschall, 2015; Wagner, 2018), the effect of parliamentary involvement on the restrictions faced by national contingents has not been structurally examined.

The answer to this question matters because it sheds light on the tension between democratic control of armed forces and military effectiveness (Wagner, Peters, \& Glahn, 2010, p. 11). On the one hand, strong parliamentary involvement in military deployment decisions is desirable from a democratic oversight perspective, given that it opens up governmental decision-making to public scrutiny and forces "governments to give reasons for political decisions" (Dieterich, Hummel, \& Marschall, 2008, p. 4; Ruys, Ferro, \& Haesebrouck, in press). On the other hand, legislative involvement threatens to undermine executive flexibility and responsiveness, thereby assumedly having a negative impact on the effectiveness of military operations. Given that national reservations are an important challenge to the effectiveness of coalition warfare, the impact of the legislative branch on national caveats 
should be accounted for to assess the desirability of parliamentary involvement in decisionmaking on the use of force.

In this article, we explore the impact of parliamentary involvement in military deployment decisions on the scope of the mandates of deployed forces. In particular, two main claims seem to emanate from the current scholarship, which we subject to empirical scrutiny. First, it has been suggested that the mandate restrictions desired by political parties depends on their ideological orientation. More specifically, right-wing parties are expected to argue in favor of restrictions if there are no clear national interests at stake in the operation, left-wing parties for restrictions on the use of military force beyond humanitarian goals. Second, prior research has suggested that parliamentary involvement tends to increase the restrictions on the mandate of deployed forces because it opens up decision-making on the use of force to opposition parties and potentially sceptical backbenchers in governing parties.

Empirically, we focus on the Belgian contribution to the 2011 military intervention in Libya and the coalition against the self-proclaimed Islamic State in Iraq from 2014 onwards. Belgium was governed by a caretaker government at the time of the Libya crisis and the 2014 Iraq intervention. Because of this particular political context, the Belgian government decided to place the decision to participate in both interventions to vote in parliament, a decision which is under normal circumstances an executive prerogative. This temporary parliamentarisation of war powers provides a unique opportunity to examine the impact of parliamentary involvement on what national militaries are allowed in multinational coalitions. We show that the Belgian case raises doubts over the conventional wisdom that parliamentary involvement increases national restrictions in coalition warfare.

\section{Parliamentary involvement and national restrictions}

Scholarly literature on national caveats began with a seminal article and subsequent book-length study of Auerswald and Saideman $(2012,2014)$ on NATO's ISAF operation in Afghanistan. In 
this groundbreaking work, the authors demonstrate that restrictions on mandates of national contingents are driven by domestic political institutions. More specifically, they concentrate on the difference between individual and collective decision-making. Whereas presidents and prime ministers can decide relatively independently on the use of force in presidential regimes and single party governments, contributions of coalition governments are the result of bargaining between members of different parties (Auerswald \& Saideman, 2014, p. 65). Because enthusiasm for deployment is likely to vary amongst coalition partners and since the threat of government dissolution forces leaders to take the preferences of less enthusiastic partners into consideration, the authors expect coalition governments to be inclined to impose tighter restrictions on their military contingents. Building on the work of Auerswald and Saideman (2014), Frost-Nielsen (2017) examines whether caveats in the Libya operation were the result of a bargaining process among political actors in domestic decision-making. More specifically, one of his hypotheses is that "caveats are the negotiated compromise between a government proposing to support a coalition militarily and opposition parties with veto powers skeptical to the government's proposal" (Frost-Nielsen, 2017, p. 6). Rather than considering constraints on the mandates of military operations the result of intra-coalition bargaining, this hypothesis assumes these are the result of a compromise between government and opposition parties. Given that the latter are only represented in parliament, this suggests that parliamentary involvement in military deployment decisions makes restrictions more likely.

The latter resonates with the expanding scholarly debate about whether strong parliamentary involvement restricts a government's ability to participate in (coalition) warfare. Several studies confirm the restriction on war involvement conjecture. Choi (2010, p. 438), for example, shows that legislative constraints "are likely to discourage democratic executives' use of force”. Reiter and Tillman (2002, p. 824), in turn, conclude that greater legislative control over foreign policy is associated with lower propensity to initiate conflicts. Likewise, a study 
of European involvement in the 2003 Iraq intervention by Dieterich, Hummel, \& Marschall (2015) confirms that strong parliamentary war powers are associated with weak degrees of war involvement. In contrast, a book-length study by Patrick Mello (2014, p. 186) on the military interventions in Afghanistan, Iraq and Kosovo only provides mixed support for the parliamentary peace proposition. Wagner (2018), in turn, studies patterns of participation across 25 to 35 countries in five military missions. He finds modest evidence for the impact of parliamentary involvement on military deployments and concludes that its impact depends on the character of the military mission in question.

In combination with the "domestic-bargaining-hypothesis" of Frost-Nielsen (2017), these insights from literature on "parliamentary peace" raise the expectation that parliamentary involvement in military deployment decisions restricts the mandates of the deployed forces. More specifically, parliamentary involvement is expected to open up the decision-making process to members of opposition parties, who might be more skeptical on the deployment of national forces. However, there is an increasing scholarship on how preferences on mandate restrictions tend to correlate with the ideological orientation of political parties represented in parliament (Mello, 2012). After testing one of the most sophisticated models of the impact of domestic-level conditions, Mello (2012) concludes that only left-leaning parliaments constitute an effective veto point against military contributions to Operation Iraqi Freedom. ${ }^{1}$ This corresponds to the tested assumption that right-wing parties are generally more supportive of military interventions than left-wing parties. Palmer, London, \& Regan (2004) assume that political leaders, above all, want to remain in office. Since the electoral platforms of rightleaning parties are generally more pro-military than those of left-leaning parties, right-wing governments should be more likely to resort to the use of force. The analysis by Palmer, London

\footnotetext{
${ }^{1}$ In contrast, the study of Haesebrouck (2018) on the pattern of participation in the air strikes against IS suggests that parliamentary veto power is a relevant condition for military deployment decisions, irrespective of partisan politics.
} 
and Regan (2004), as well as the successive study of Arena and Palmer (2009), confirms this inference. Likewise, Schuster and Maier (2006, p. 233) conclude that left-wing parties were more inclined to object to the 2003 Iraq War, while Stevens (2015) shows that the UK's leftist prime minister Blair paid a higher political price for the Iraq War than the US' right-wing president Bush. Finally, the study of Massie (2016, p. 106) suggests that right-leaning executives tend to slow down decisions to withdraw from combat operations. In line with these studies, Auerswald and Saideman (2014, p. 69) assume that left-wing coalitions are more likely to impose tighter restraints on how operations are conducted.

However, academic research has moved beyond examining the binary distinction between the pro-military right and the pro-peace left. More specifically, scholars have developed more complex hypotheses on the differences between left- and right-wing parties on military action. Rathbun (2004) has introduced a three-dimension model, which suggests that leftist parties are not only more antimilitaristic, prefer operating under multilateral frameworks and have a broader conception of the national interest, which comprises the promotion of human rights (Rathbun, 2004, pp. 18-21). Rightist parties, in turn, have a more narrow conception of the national interest, consider the use of force an acceptable instrument in international relations, and are more reluctant to delegate control to multilateral institutions. Building on the model of Rathbun, Frost-Nielsen (2017, p. 6) expects rightist parties to be in favor of national restrictions if there are only limited national interests at stake in the mission, while left-wing parties are expected to be in favor of restrictions to avoid "excessive use of force outside the humanitarian mandate of the mission".

Building on this prior research, two main expectations can be formulated. First, parliamentary involvement can be hypothesized to increase the restrictions on the mandate of deployed forces because it opens up decision-making on the use of force to opposition parties. Second, the mandate restrictions desired by political parties is expected to depend on their 
ideological orientation. More specifically, right-wing parties can be expected to prefer restricted mandates if there are no clear national interests at stake in the operation, left-wing parties tend to prefer restrictions on the use of military force beyond humanitarian goals. To test these propositions, we first assess whether or not the arguments provided by members of the Belgian parliament (MPs) in the debates in the Belgian House of Representatives on participating in the Libya intervention (2011) and the air strikes against IS over Iraq (2014) are indeed in line with the expectations derived from literature on the link between party ideology and desired mandate restrictions. Subsequently, we discuss the actual impact of this temporary parliamentarisation on the outcome of the mandate negotiations for the Belgian military contribution to the examined operations.

\section{Case selection}

Belgium's participation in the military interventions in Libya (2011) and the coalition against IS in Iraq (2014-2017) provides two unique opportunities to test the conventional wisdoms of the literature on parliamentary restrictions. As the Belgian government found itself at both occasions in a caretaker states, there was debate about its constitutional prerogative to autonomously decide upon military troop deployments (Fonck \& Reykers, 2018; Reykers \& Fonck, 2016). As a result, both decisions were exceptionally brought to parliament for a formal vote of approval. In the Libya case, the decision to participate with six F16 fighter jets, a marine minesweeper and approximately 200 military support personnel was voted upon on 18 March 2011, receiving a quasi-unanimous parliamentary support. On 26 September 2014, also the decision to deploy again six F16 fighter jets and an additional 120 military support troops to Iraq again received convincing parliamentary support, with only the extreme-left Partij van de Arbeid-Parti du Travail de Belgique (PVDA-PTB) voting against and the green Ecolo-Groen fraction abstaining. 
Following the caveats literature, one would expect that these exceptional episodes of parliamentary involvement impacted the mandate of the Belgian contribution to both coalitions. In their analysis of national restrictions on the ISAF operation in Afghanistan, Auerswald and Saideman (2014, p. 208) already briefly referred to the Belgian participation in the Libya intervention, framing it as "perhaps the most interesting and underrated part of the Libyan campaign". Remarkably, however, they suggested that while Belgian forces "faced significant restrictions in Afghanistan", its active engagement in the air strikes over Libya was guided by a mandate "with little restrictions". The authors not only refer to the humanitarian nature of the intervention as a potential explanatory factor, but also point at domestic political factors. The caretaker status of the Belgian government in 2011 is suggested to having created a situation with "essentially no veto-players", which, according to them, together with a large parliamentary support might explain for this rather forceful mandate (Auerswald \& Saideman, 2014, p. 208).

Against the background of findings about how parliamentary involvement leads to higher national restrictions in coalition warfare, the forceful participation of Belgium in the Libya and Iraq interventions are indeed puzzling observations. They seemingly contradict the aforementioned findings about the determining effect of domestic bargaining, and hence require closer scrutiny.

\section{Libya operation}

The military intervention in Libya was launched in response to the brutal repression of the Libyan uprising by the Qaddafi regime. On 17 March 2011, the UNSC adopted resolution 1973, which established a no-fly zone over Libya and authorized all necessary measures to protect civilians under threat of attack. Military action to enforce this resolution began two days later and ended in October 2011. The operation started as an ad hoc coalition, but NATO took command ten days after its launch. 


\section{Party-politics and the mandate preferences for the Libya operation}

Following UNSC resolution 1973, the Libya intervention primarily focused on the protection of civilians under threat of attack and the enforcement of a no-fly zone. Statements by government leaders of participating coalition members, including those of Belgium, reflected this overarching humanitarian framing. For instance, Prime Minister Leterme declared before parliament on 21 March 2011 that "Resolution 1973 of the UN Security Council confirmed the responsibility of the international community to protect the Libyan population against attacks" and "the Libyan population needs our support now" (Belgische Kamer van Volksvertegenwoordigers, 2011a, pp. 3-4). In consequence, building on the aforementioned literature, we expect left-wing parties not to argue in favor of general restrictions on the tasks of deployed forces, but instead to restrict the mandate towards protecting the Libyan population. Given that there were no clear Belgian interests at stake in the operation, we would expect rightwing parties to prefer a more restricted mandate for the deployed forces.

The parliamentary debates provide mixed support for these expectations. The MPs that took the floor during the extensive discussions on Belgian participation in the military operations in the plenary session of 17 and 21 March 2011 and the Joint Committee for External Relations and Defense of 18 March 2011 consistently supported military action in Libya for protecting the population against mass atrocities. Neither members of right-leaning or leftleaning parties argued that there were clear interests at stake to motivate their support for military action. In consequence, we would expect right-wing parties to be in favor of a more limited goal. However, MPs of right-wing parties generally did not argue for putting restrictions on the Belgian contribution. Intervening right-wing and centrist members mentioned that Belgium should stay within the limits of the UN Resolution, but were not explicit on which the goals of the operation (Belgische Kamer van Volksvertegenwoordigers, 2011a, pp. 22, 27). In the debates on the Belgian contribution, right-wing conservative members even argued that the 
operation could, in fact, pursue regime change. They furthermore claimed that the military intervention would make the deportation of Qaddafi to the International Criminal Court in The Hague possible (Belgische Kamer van Volksvertegenwoordigers, 2011a, p. 39).

Members of left-wing parties did argue to keep the operation focused on the protection of civilians. During the debate of 18 March 2011, members of the [Flemish] socialist party and the [Walloon and Flemish] green parties did argue that the intervention should pursue limited and very clear goals (Verenigde Commissies voor de Buitenlandse Betrekkingen en voor de Landsverdediging, 2011, pp. 13-16,25). One socialist MP, for example, explicitly warned not to pursue regime change or nation-building. In the plenary session of $21 \mathrm{March}$, when parliament almost unanimously adopted the resolution on participation in the operation, members of the socialist and green parties put strong emphasis on the necessity of staying within the limits of the UN resolution and avoiding that the operation would pursue other goals than protecting the Libyan population. Left-wing social democrats argued that it must be avoided that the operation results in an occupation or in an offensive operation. They furthermore explicitly warned against mission creep, thereby joined by a green member who argued the operation should not result in regime change (Belgische Kamer van Volksvertegenwoordigers, 2011a, pp. 8, 14, 18). Finally, green and socialist MPs furthermore insisted on the necessity of avoiding collateral damage and civilian victims (Belgische Kamer van Volksvertegenwoordigers, 2011a, pp. 16, 18).

As the operation progressed, MPs of the socialist and green parties asked critical questions on whether or not the operation was overstepping UNSC resolution 1973. This included remarks from MPs of the socialist parties on the 10 May in the Foreign Affairs Committee, pointing at the fact that Qaddafi and his family were targeted by coalition air strikes. They claimed that the operation had evolved from a humanitarian intervention into an intervention that assisted in a civil war (Commissie voor de Buitenlandse Betrekkingen, 2011, 
pp. 3,7 ). The same issues also resulted in animosity within the parliament's Committee on Defence, where on June 1st, a green member expressed his concern on the fact that the operation was getting involved in a civil war, while the primary goal should be the protection of the Libyan population (Commissie voor de Landsverdediging, 2011, p. 28). In the plenary debate that same day, a socialist MP concluded that the operation in Libya had already gone far beyond the mandate provided by the UNSC (Belgische Kamer van Volksvertegenwoordigers, 2011b, p. 2).

The debates in the Belgian parliament thus partly confirm the expectations derived from the literature on the link between political ideology and the desired restrictions on the mandate of military operations. In line with these expectations, left-leaning parties indeed argued against exceeding the humanitarian mandate of the operation and limiting it to the protection of civilians. However, in contrast to theoretical expectations, right-wing parties did not argue for restrictions on the deployed forces, in spite of the absence of clear Belgian interests in the operation.

\section{The mandate negotiation of the Belgian contribution}

Given the involvement of parliament, thus including the opposition parties, in the decisionmaking process for the Libya intervention, we would expect restrictions also being imposed on the mandate of the Belgian contribution. Remarkably, however, the parliamentary resolution that authorized Belgian participation was far from a limited mandate. It requested the government to "actively collaborate in the implementation of the UNSC resolution" and did not impose limitations in terms of the duration of the Belgian involvement (Belgische Kamer van Volksvertegenwoordigers, 2011c, para 2). Perhaps most strikingly, the resolution furthermore contained the message that "conditions are fulfilled for a military action against the regime of Qaddafi”, an issue which seemingly passed the Belgian parliamentary vote unnoticed (see also Reykers \& Fonck, 2016; Fonck \& Reykers, 2018). 
Retracing the negotiations leading up to the final mandate, the reasons for this remarkably broad and permissive mandate appear to be twofold. First, the parliamentary resolution was meticulously prepared by the Foreign Affairs department, instead of by the parliament itself (Reykers \& Fonck, 2016: 99). Limited by the rapidity of the decision-making process, parliament needed to discuss and agree on a pre-drafted mandate during one afternoon on the basis of an executive-drafted mandate. Second, and most crucially, interviews show there was a strong cross-party parliamentary consensus on the desirability to intervene, fed by a general resentment over Qaddafi's threats towards the opposition movements and by the opposition's strong indignation over an earlier decision of the Belgian government to approve Libya's candidacy for a seat in the UN Human Rights Council a year earlier (Interview with Foreign Affairs Official, 17 April 2015). It has been shown elsewhere how officials within the Foreign Affairs department were aware of this general atmosphere, leading them to strategically exploit this momentum (Fonck \& Reykers, 2018).

That having said, the green and socialist opposition parties did however succeed in slightly restricting the mandate elsewhere. Together with majority members they negotiated and subsequently proposed an extra condition to the parliamentary mandate which stipulated that parliamentary consultation is again required "whenever new circumstances would change the nature of the Belgian engagement” (Belgische Kamer van Volksvertegenwoordigers, 2011c, p. 5). This seems to be in line with Frost-Nielsen's (2017) argument that opposition parties stand sceptical to a government's proposal and will therefore seek to limit its leeway.

Concluding, the debates in parliament are clearly in line with expectations on party ideology and desired mandate restrictions, confirming the first hypothesis. A less clear verdict can be made with regard to the effect of opposition parties on the outcome of mandate bargaining. Frost-Nielsen's expectation that the inclusion of opposition parties, skeptical to the government's proposals, will result in mandate restrictions, seemed to have been mitigated by 
the orchestrated nature of the parliamentary involvement which inhibited a genuine government-opposition bargaining process to take place. Given these mixed results, the second hypothesis does not appear to fully hold for the case of Libya.

\section{Anti-IS Coalition}

International military action against IS began on 8 August 2014, after IS forces began to pose an immediate threat to the Kurdish capital Erbil and created a humanitarian crisis in Northern Iraq. The Belgian government agreed on 24 September 2014 to contribute with six F16 fighter

jets against IS in Iraq. Starting from February 2015, Belgium also deployed around 50 instructors to train and advice Iraqi forces. The Belgian contribution to the air campaign was paused on 30 June 2015, as part of a rotation agreement with the Netherlands.

\section{Party-politics and the mandate preferences for the anti-ISIL coalition}

One of the main reasons cited by the Belgian government for its participation in the anti-ISIL coalition in Iraq was the fight against terrorism and the particular security threat posed by returning ISIL fighters. As Belgium appeared to be one of the most fertile breeding grounds for foreign ISIL fighters, the international conflict was framed as representing a particular national concern for the government. The domestic politicisation of the issue was further fed when, in June 2014, a returned foreign fighter killed four people in a terrorist attack at the Jewish museum in Belgium. Testimony to this is the discourse of the foreign affairs minister in Parliament on the $24^{\text {th }}$ and $25^{\text {th }}$ of September, where he stated that the 'presence of foreign fighters makes this issue not only a Syrian or Iraqi one, but also directly implicate Belgium’ (Verenigde Commissies voor de Buitenlandse Betrekkingen en voor de Landsverdediging, 2014a/2014b). In addition, humanitarian arguments guided the government's decision to participate in the operation, such as there was the humanitarian crisis following the horrific attacks of ISIL on Christian and Yezidi towns in Northern Iraq (Ibid; Henderson, 2014, p. 209). 
Because of the more tangible Belgian interests at stake, we expect the right-wing parties to not argue in favour of general restrictions on the tasks of deployed forces. In contrast, we would expect left-wing parties to argue for more restrictions, except for operations with a clear humanitarian goal.

The decision to participate in the air operations in Iraq was discussed in the Joint Committee of External Relations and Defence and during a plenary session, which resulted in a resolution that authorized military action in Iraq. A large majority of the parliament voted in favour of the resolution. Only the two members of the extreme left PTB voted against the resolution, while members of the green parties abstained.

During the debates, members of left-wing parties were clearly less supportive than members of the centrist and right-wing parties. The MPs that took the floor consistently referred to the mass atrocities committed by IS as one of the main reasons for supporting the intervention. Several MPs also pointed at the threat to Belgian national security, posed by IS (Belgische Kamer van Volksvertegenwoordigers, 2014a, pp. 20, 38, 44). A liberal and centrist MP referred to the attack at the Jewish museum and the threat posed by the 400 Belgian nationals that joined IS. Two other liberal members even explicitly argued that IS posed a terrorist threat to Belgian society, making them conclude that one of the reasons to support military action was avoiding that Iraq would become a safe haven for international terrorism (Verenigde Commissies voor de Buitenlandse Betrekkingen en voor de Landsverdediging, 2014a, p. 16). Finally, the extreme-right framed the operation as an intervention against radical Islam, which in his view poses a threat to Western societies more in general (Belgische Kamer van Volksvertegenwoordigers, 2014a, p. 45).

With regards to the mandate of the deployed forces, there were clear differences on whether or not Belgian fighter jets could also operate over Syrian territory. All green and socialist parties argued that in the absence of a mandate of the Security Council and a request 
of the Syrian government, there was no legal basis for conducting air operations over Syria and, therefore, the Belgian operation should remain restricted to Iraq. In contrast, an extreme-right MP questioned whether the operation should be restricted to Iraq, given that IS does not care about UN mandates (Belgische Kamer van Volksvertegenwoordigers, 2014a, p. 47). Centrists, in turn, argued that the Security Council was losing legitimacy because the veto power of Russia and China was keeping it from taking action against the mass atrocities that were taking place in Syria (Belgische Kamer van Volksvertegenwoordigers, 2014a, p. 38). The right-wing conservative N-VA was most strongly in favour of operating above Syria. Next to calling into question the legitimacy of the UNSC, which according to his argument was taken hostage by Russia, it was argued the party was not principally opposed to an intervention in Syria (Verenigde Commissies voor de Buitenlandse Betrekkingen en voor de Landsverdediging, 2014a, p. 23). On top of that, they requested to be "pragmatic" with regards to Belgian fighter jets crossing the border between Iraq and Syria (Belgische Kamer van Volksvertegenwoordigers, 2014a, p. 7). This led to a strong reply from the socialists and greens, who asked not to be pragmatic when it comes to international law (Belgische Kamer van Volksvertegenwoordigers, 2014a, pp. 7, 25).

The debates in the Belgian parliament, thus, confirm the expectations derived from the literature on the link between political ideology and caveats. In line with these expectations, left-leaning parties wanted a more limited mandate for the operation and argued against expanding operations to Syria. In contrast, members of right-wing parties did not argue for restrictions on the deployed forces and did not oppose extension to Syria.

\section{The mandate negotiation of the Belgian contribution}

Contrary to the Libya intervention, the parliamentary involvement in the decision about the Belgian military contribution in the coalition against ISIL in Iraq resulted in more significant restrictions being introduced by the opposition parties. 
Informal negotiations on the scope of the mandate were initiated by the outgoing government, who proposed to have discussions on a draft version of the parliamentary resolution, involving both past and future coalition parties while also reaching out to opposition parties. The decision to extend talks to the opposition was particularly instructed by a desire of the incumbent-yet-in-dismissal government to assure the future to the incoming would-be majority would also support and carry out the decision to intervene (Fonck and Reykers, 2018: 15). Negotiations therefore largely followed government-opposition dynamics reflecting the incoming government coalition, and resulted in three significant amendments. ${ }^{2}$ First, green and socialist opposition parties managed to limit the mandate of the intervention to the Iraqi territory, against the will of right-wing MPs who were in favour of including Syria. Second, the socialists also opposed including any reference to 'training, advising and assisting' or 'special exploratory missions' tasks in the final parliamentary resolution, which implied the possible deployment of special forces. Third, upon request of the greens and socialists, the parliamentary resolution explicitly stipulated a time limitation, in the sense of granting the government permission to participate in the intervention only 'for the duration of one month . Finally, after the resolution was introduced to parliament, the greens still managed to strengthen a provision on the safeguarding of human rights just before it was put to vote (Belgische Kamer van Volksvertegenwoordigers, 2014a, pp. 25-26, 28-29; 2014b, p. 4).

Concluding, our findings on the Iraq intervention not only correspond with FrostNielsen's general conception of caveats as a 'negotiated compromise' between government and opposition parties (Frost-Nielsen, 2017, p. 6). Even more, the predicted relation between political ideology and mandate preferences also determined the majority-opposition bargaining process. Parties oriented to the left were clearly willing to limit the territorial scope and action

\footnotetext{
2 Interviews with members of parliament, 6 and 7 July 2015 (Brussels); Interview with former Defence cabinet official, 21 March 2016 (Brussels).
} 
range of the operation and asked for humanitarian safeguards, while right-wing parties favoured a more maximalist intervention based on arguments of national interest.

\section{Conclusion}

This article intended to shed light on the implications of parliamentary involvement of national restrictions in coalition warfare. It analyzed, (1) the link between party ideology on mandate preferences, and (2) the impact of bargaining between majority and opposition parties on the outcome of mandate negotiations.

Overall, both case studies provide clear evidence that support the expected relationship between ideology and mandate preferences. While the literature expects right-wing preferences on mandate restrictions to be conditioned by the degree of national interests at stake in the operation, the anti-ISIL intervention clearly confirmed this tendency by showing their eagerness to intervene in Syria as well. Left-wing parties on the hand showed a strong inclination towards imposing restrictions on the use of military force beyond humanitarian goals.

With regard to the impact of opening up the decision-making on deploying forces to opposition parties, our findings are less conclusive. The case of Libya indicated that the influence of opposition parties was severely limited by a strong executive-driven and timeconstrained parliamentary consultation process, which prevented a genuine governmentopposition bargaining process from taking place. It furthermore showed that the cross-party hawkish consensus on the necessity to intervene failed to transform the opposition parties into inescapable veto players. The case of the anti-ISIL intervention at its turn, resulted in an effective negotiation process between government and opposition parties, with the latter being crucial players to have on board, as it included future majority members of the incoming government. In short, our study suggests that the impact of opposition parties as effective veto players on mandate bargaining is dependent on a sufficient degree of contention between 
government and opposition parties, as well as on the extent to which the executive needs to seek support across its own majority. In that sense, future research should do well in prioritizing the study of domestic bargaining processes over ideological preferences.

On a more generic level, our findings touch upon ongoing debates in the parliamentarisation literature. They particularly shed new light on the cardinal question whether increased parliamentary involvement necessarily implies a victory for parliament. The mixed findings in this article raise the importance of investigating opposite tendencies of executivedriven attempts to legitimise military interventions (see also Lagassé, 2017; Fonck and Reykers, 2018), whereby parliamentary consultation reflects an orchestration rather than a democratization. This remains a key issue to be addressed, both in future research which seeks to establish the determinants of genuine democratic control on the use of military force, and in policy debates about changing parliamentary war powers.

\section{References}

Arena, P., \& Palmer, G. (2009). Politics or the Economy? Domestic Correlates of Dispute Involvement in Developed Democracies. International Studies Quarterly, 53(4), 955975.

Auerswald, D. P., \& Saideman, S. M. (2014). NATO in Afghanistan: Fighting Together, Fighting Alone. Princeton: Princeton University Press.

Belgische Kamer van Volksvertegenwoordigers. (2011a, 18 March). Integraal verslag met vertaald beknopt verslag van de toespraken. Brussels: Author.

Belgische Kamer van Volksvertegenwoordigers. (2011b, 21 March). Integraal verslag met vertaald beknopt verslag van de toespraken. Brussels: Author.

Belgische Kamer van Volksvertegenwoordigers (2011c, 21 March). Resolutie betreffende de toestand in Libië. Brussels: Author.

Belgische Kamer van Volksvertegenwoordigers. (2014a, 24 September). Integraal verslag met vertaald beknopt verslag van de toespraken. Brussels: Author.

Belgische Kamer van Volksvertegenwoordigers. (2014b, 26 September). Resolutie betreffende de toestand in Irak en de deelneming van België aan de internationale coalitie tegen IS. Brussels: Author. 
Choi, S. W. (2010). Legislative Constraints: A Path to Peace? Journal of Conflict Resolution, 54(3), 438-470.

Commissie voor de Buitenlandse Betrekkingen. (2011, 10 May). Integraal verslag met vertaald beknopt verslag van de toespraken. Brussels: Author.

Commissie voor de Landsverdediging. (2011, 1 June). Integraal verslag met vertaald beknopt verslag van de toespraken. Brussels: Author.

Desch, M. C. (2002). Democracy and victory: Why regime type hardly matters. International Security, 27(2), 5-47.

Dieterich, S., Hummel, H., \& Marschall, S. (2008). Strengthening parliamentary" war powers" in Europe: lessons from 25 national parliaments. Geneva: Geneva Centre for the Democratic Control of Armed Forces.

Dieterich, S., Hummel, H., \& Marschall, S. (2015). Bringing democracy back in: The democratic peace, parliamentary war powers and European participation in the 2003 Iraq War. Cooperation and Conflict, 50(1), 87-106.

Fonck, D., \& Reykers, Y. (2018). Parliamentarisation as a Two-Way Process: Explaining Prior Parliamentary Consultation for Military Interventions. Parliamentary Affairs. Advance online publication. doi:https://doi.org/10.1093/pa/gsx081

Frost-Nielsen, P. M. (2017). Conditional commitments: Why states use caveats to reserve their efforts in military coalition operations. Contemporary Security Policy, 38(3), pp. 371397. Advance online publication. doi:10.1080/13523260.2017.1300364

Haesebrouck, T. (2018). Democratic participation in the air strikes against Islamic State: A qualitative comparative analysis, Foreign Policy Analysis, 14(2), 254-275.

Henderson, C. (2014). The Use of Force and Islamic State. Journal of the Use of Force and International Law, 1(2), 209-222.

Lagassé P. (2017). Parliament and the War Prerogative in the United Kingdom and Canada: Explaining Variations in Institutional Change and Legislative Control. Parliamentary Affairs 70(2), 280-300.

Massie, J. (2016). Why Democratic Allies Defect Prematurely: Canadian and Dutch Unilateral Pullouts from the War in Afghanistan. Democracy and Security, 12(2), 85-113.

Mello, P. A. (2012). Parliamentary Peace or Partisan Politics? Democracies' Participation in the Iraq War. Journal of International Relations and Development, 15(3), 420-453.

Mello, P. A. (2014). Democratic Participation in Armed Conflict Military Involvement in Kosovo, Afghanistan and Iraq. Basingstoke: Palgrave Macmillan. 
Mello, P. A. (2016). Domestic Politics and Foreign Policy Change: Analyzing Withdrawal from Coalition Operations in Iraq. Paper presented at the European Workshops in International Studies, Groningen, June 2018.

Palmer, G., London, T., \& Regan, P. (2004). What's Stopping You? The Sources of Political Constraints on International Conflict Behavior in Parliamentary Democracies. International Interactions, 30(1), 1-24.

Rathbun, B., C. (2004). Partisan Interventions: European Party Politics and Peace Enforcement in the Balkans Ithaca: Cornell University Press.

Reiter, D., \& Tillman, E. R. (2002). Public, Legislative, and Executive Constraints on the Democratic Initiation of Conflict. The Journal of Politics, 64(3), pp. 810-826.

Reykers, Y., \& Fonck, D. (2016). Who is controlling whom? An analysis of the Belgian federal parliament's executive oversight capacities towards the military interventions in Libya (2011) and Iraq (2014-2015). Studia Diplomatica, 68(2), 91-110.

Ruys, T., Ferro, L., \& Haesebrouck, T. (in press). Parliamentary War Powers and the Role of International Law in Foreign Troop Deployment: Decisions the US-Led Coalition against 'Islamic State'in Iraq and Syria. International Journal of Constitutional Law.

Saideman, S. M., \& Auerswald, D. P. (2012). Comparing caveats: understanding the sources of national restrictions upon NATO's mission in Afghanistan. International Studies Quarterly, 56(1), 67-84.

Schuster, J., \& Maier, H. (2006). The Rift: Explaining Europe's Divergent Iraq Policies in the Run-Up of the American-Led War on Iraq. Foreign Policy Analysis, 2(3), 223-244.

Stevens, D. (2015). War and Elections. International Studies Quarterly, 59(3), 477-489.

Tago, A. (2009). When Are Democratic Friends Unreliable? The Unilateral Withdrawal of Troops from theCoalition of the Willing'. Journal of Peace Research, 46(2), 219-234.

Verenigde Commissies voor de Buitenlandse Betrekkingen en voor de Landsverdediging. (2011, 18 March). Integraal verslag met vertaald beknopt verslag van de toespraken. Brussels: Author.

Verenigde Commissies voor de Buitenlandse Betrekkingen en voor de Landsverdediging. (2014a, 24 September). Gedachtenwisseling de toestand in Irak en de eventuele deelneming van België aan de internationale coalitie. Brussels: Author.

Verenigde Commissies voor de Buitenlandse Betrekkingen en voor de Landsverdediging. (2014b, 25 September). Gedachtenwisseling over de toestand in Irak. Brussels: Author.Wagner, W. (2018). Is there a parliamentary peace? Parliamentary veto power 
Accepted Version - Contemporary Security Policy - https://doi.org/10.1080/13523260.2018.1500819

and military interventions from Kosovo to Daesh. The British Journal of Politics and International Relations, 20(1), 121 - 134.

Wagner, W., Peters, D., \& Glahn, C. (2010). Parliamentary War Powers Around the World. Geneva: Geneva Centre for the Democratic Control of Armed Forces. 